\title{
Keeping the Dialectic Open for Music Education
}

Eight Essay Reviews of Remixing the Classroom: Toward an Open Philosophy of Music Education, by Randall Everett Allsup (Indiana University Press, 2016)

\author{
Vincent C. Bates, Editor \\ Weber State University, Utah, USA
}

This article explores four reasons for devoting a review issue of Action, Criticism, and Theory for Music Education to Randall Allsup's Remixing the Classroom: Toward an Open Philosophy of Music Education. First, Allsup seems to recognize the social, cultural, and somatic situatedness of his own thinking, a materialist and constructionist stance consistent with ACT's focus in critical social theory. Second, Allsup's approach further complements the ideals of the MayDay Group. Third, Allsup directly challenges praxial philosophies of music education that have been and continue to be foundational in ACT and the MayDay Group-a challenge that calls for a response. Finally, in his dialectical struggle between open and closed forms, Allsup foregrounds openness and rupture, a necessity in efforts for emancipatory change music education.

Keywords: Allsup, praxis, dialectic, music education, critical theory

ll philosophy is autobiography. After all, philosophy is something people
do. People. Historically, socially, and somatically situated, our doings
and beings stem from primarily subconscious inner landscapes (see Lakoff and Johnson 1999). Even philosophy, despite its deliberateness, tends to become "the confession of its originator, and a species of involuntary and unconscious auto-biography..." (Nietzsche 1910). Especially considering the ubiquity of critical discourse analysis, the performative acts of philosophers-to publish their framings of socially constructed and embodied conceptualizations-inevitably exposes them to the critical gaze of others. Yes, there is much that can be gained professionally and personally from writing a book. But still, anyone willing to 
"bare it all" and (figuratively) walk naked through the streets deserves a degree of deference, especially if they are at least somewhat aware of their nakedness. And this is exactly what I found most refreshing about Remixing the Classroom. I didn't have to "read between the lines" to know something about the person who wrote it. For instance, Allsup writes:

As a gay white male, I have always understood "identity" as something one can and can't control, as something complex and evolving, with parts that are fixed. I am, after all, at the intersection of great privilege and societal disgust. And, like my students, I am much more than you can see, and more than I can tell you. I am a text, like my fellow students, like our classroom, like our community. (105)

Much of the book's strength derives from this consciousness of self, or at least the attempt to "give an account of oneself" (Butler 2005), which is key in critical analyses with emancipatory aims. From a materialist perspective, Eagleton (2016) writes:

We are also the product of history, heredity, systems of kinship, social institutions and unconscious processes. These are not for the most part things we choose. They, too, weigh in upon us like impersonal powers, even though (with the exception of biology) they are at root human creations. The human subject is thus always to some degree a stranger to itself, constituted by powers it is incapable of fully appropriating; and that this is so is part of the materialist case.... [However] That we are a product of so many forces is not to claim with the eliminativists that human agency is a self-serving myth. It is rather to insist that what self-determination we can achieve exists within the context of a deeper dependency. (kindle 274-7 and 281-3, emphasis added)

When people philosophize, what arises in consciousness is a "muddle" (Allsup's term) of socially and somatically embedded concepts that, again following Butler (2005), tends to be more opaque than transparent. Yet the effort to know oneself is integral in that it fosters "a disposition of humility and generosity alike: I will need to be forgiven for what I cannot have fully known, and I will be under a similar obligation to offer forgiveness to others, who are also constituted in partial opacity to themselves" (Butler 2005, 42, emphasis added). Allsup's philosophy, I submit, is a clear instance of someone recognizing their own fallibility (as prominently recommended for music education philosophers by Wayne Bowman and Lucía Frega in the Oxford Handbook of Philosophy in Music Education 2012). Without this sense of humility and generosity, critical social theory lacks the necessary integrity to truly understand social and ecological injustices or have any 
real hope of transforming music education to better meet the needs of real students, in real places.

Through multiple readings of Remixing the Classroom, I conducted a rather informal critical discourse analysis. It seemed to me that many concepts and perspectives did indeed reflect the author's personal/cultural/social biases-takenfor-granted and/or left unexamined, particularly (for me) pertaining to middle class and urban(e) ideals. It was rather disarming, then, to come upon passages such as the following:

As I reread the paragraph above, my heart sinks, I feel like a fraud, lonely in my house in Vermont, dreaming up bourgeois nonsense. What right have I to make a case for open classrooms and constructed knowledge-this philosophy of foraging-when my future teachers will be evaluated by their students' test scores, when lesson plans must include action deliverables, and when, all the while, their careers depend on proof of their value... In my darkest place, I wonder if the philosophy I have cooked up is for my self-actualization, not theirs-or worse, at their expense. (129)

This courage to go into dark places, to face one's own boundedness and limitations-one's own potential complicity in harm to people and planet-to embrace humility, to relinquish the desire to compete, win, or dominate-is, (perhaps paradoxically) rather inspiring. In music education philosophy, particularly in monographs such as this, it is somewhat unique-and welcome!

Another reason for reviewing Remixing the Classroom is simply that Allsup's open philosophy complements the ideals of the MayDay Group (MDG), the emancipatory aims of critical social theory, and our collective longings for change in music education. In fact, Allsup's desire "to be more open in helping students design experiences that fund their needs and wishes" sounds to me a lot like the praxial philosophies for music education that I have grown to know and love. For instance, recall some of the words of Tom Regelski (2009):

Just as musical praxis varies in value and meaning according to situated use, so music education as and for praxis needs to vary according to the situated circumstances of teachers and their schools-which are as different and relevant in their diversity as, for example, the differences are between the patients a doctor treats and the local circumstances of a doctor's practice. Ideas of standard practice (i.e., methodolatry) would give way to the ethical standards of care of reflective praxis that are characteristic of all helping professions. The idea of standard results (or "standards") would give way to the norm of making a pragmatic musical difference (in various ways, according to need, interest, ability, etc.) for students served, and thus for society. The most basic criteria 
guiding such reflective teaching praxis (and for evaluating its effectiveness) are: What is each student able to do, at all or better, as a result of instruction? What musicking does the typical student choose to do as a result of 'school music'? (76, emphasis added)

Of Dapper Dan's work, a central story in the book, Allsup writes, "On some level this is an emancipatory process, one that takes the lingua franca of global power, hierarchy, and oppression and bends it to local needs" (6). Likewise, the agenda of critical theory, which serves as a core approach in the MDG and ACT, is "emancipation from social domination" (Mills 2017, kindle 236), including bending current circumstances (as Regelski suggests in the above quotation) according to local diversity.

Allsup is particularly concerned about closed forms in music education, discussions of which (throughout and constituting the tenor of his book) bring to my mind Regelski's (e.g. 2006) criticisms of institutionalization in music education and "music's distantiation from society" (4). Allsup writes: "Put simply, within our public-school music programs and university teacher-preparation programs there exists a critical imbalance, favoring preservation and authority over creativity and the imagination, in our obligation to teach the children and young adults in our care" (55). This language neatly parallels the MDG Action Ideals (2012): "Musical cultures are human-driven, living processes, not merely sets of works or established practices. Musical activity develops out of an emergent synergy of change and tradition within human contexts and communities of practice. Thus, we need to foster the capacity for change in our musical and educational traditions" (III). Suffice it to say, Allsup's text is punctuated throughout with key points that correspond to what one might typically encounter in ACT and other forums within the MDG (which, of course, includes work that Allsup has done within ACT and the MDG).

I found it curious (and disconcerting) then, that a considerable portion of the book is devoted to critiques of praxial philosophies of music education as closed forms, in particular attacks on David Elliott's conception of praxis. For instance, Allsup writes:

Elliott positioned his praxial methodology as a new philosophy of music education, but it is actually terribly old. Conserving a method that Western music educators have been practicing for centuries, he merely changed the rationale for why we teach and learn in closed forms. Rather than call on nineteenth-century aesthetic principles that had fallen out of fashion, and without proposing a new

Bates, Vincent C. 2017. Keeping the dialectic open for music education. Action, Criticism, and Theory for Music Education 16 (1): 1-9. doi:10.22176/act16.1.1 
method of teaching in return, Elliott merely substituted late-twentieth-century multicultural codes for those universalist tropes that were still haunting the university... (31-2).

It is not just the content, but also the tone that is troublesome here. For instance, why are old things so terrible? Are we to imagine Elliott as some sort of specter, or a huckster putting fresh labels on old items and selling them as new? Furthermore, given the (well-publicized) aversion praxial theorists have expressed toward methodology, what are we to make of Allsup's apparent contradiction: "praxial methodology"? This feels personal; it is unfortunate that wedges might be driven where there is so much potential for solidarity. Of course, it is not the purpose of ACT or the MayDay Group to promote or defend our "founders." We are not a "fan club." However, praxial philosophies have been and continue to be influential in our existence as a group; to mischaracterize praxial philosophies as primarily closed forms implicates a much larger and ongoing effort to affect change in music education. If for nothing else, this issue of ACT gives "praxial philosophers" in music education an opportunity to respond.

Finally, in addition to complementing and/or challenging key tenets of the MDG and praxial philosophies in music education, Allsup's open philosophy contributes what I believe is a key insight in the interest of "action for change":

I have taken pains in this chapter to describe the ideals of the laboratory as the result of a beautiful dialectic of the conservative and the forward thinking. I have explored how an appreciation of the past might be embodied in the metaphor of the living museum. Because I insist on continuity as much as innovation, my approach cannot be described as radical. Though the open classroom has an outline, a form with structure, there is never an absolute or radical break from the past: there is only a reordering of lived and recorded events. (92, emphasis added)

For the MDG, there is nothing particularly ground-breaking about this dialectical approach. Again, the dialectical struggle against domination and oppression is central to critical theory, critical pedagogy, and praxis. However, I'm not sure Allsup is fully committed to balancing or resolving the dialectic. Inspired by Freire, Allsup writes: "Oppression, the love of overwhelming control, is by nature an effort to silence alternative voices. In this way, relationships of control damage not only the soul-life of an apprentice but the Master's, too. Indeed, the Master loses a source of self-knowledge in his desire to control and silence others, and thus his own journey may narrow along with that of his apprentice" (11). 
On a macro-level, we might consider, as an overarching Master-apprentice model, interactions between the "developed" world and the "third" world, more appropriately referred to as the "one-third" and the "two-thirds" world (Esteva and Prakash 2014). Rhetoric within the one-third world reflects intentions to "help" and "save" the two-thirds world through technological, educational, and cultural "progress" and "development." (I think of the humanitarian trips embarked on from the institution at which I teach to destinations throughout the two-thirds world, typical of higher education efforts throughout universities within the one-third world.) This relationship between worlds, however, is actually one of exploitation, control, and oppression under the guise of assistance-a classic colonialist reality. "The entire edifice of dominant science, technology, and economics is based on transforming the commons into commodities, presenting commodification as creation, when in fact it is destruction-of ecosystems, of local economies, of cultures" (Shiva 2014). And loss of the commons through enclosure, commodification, and exploitation ultimately (reflecting Allsup's wording above) threatens the well-being of the Master as much as it does the apprentice. The Master's long-term security and, in the case of climate change, his survival, could very well depend on his ability to relinquish authority and listen to and learn from his apprentices-to relinquish the role of Master altogether.

But, what typically happens, as Ciccariello-Maher (2017) has recently pointed out, is that the dialectic, broadly understood as "the dynamic movement of conflictive opposition" (kindle 169-70), becomes an instrument of continued domination in establishing a middle ground, a unity "to deactivate unruly movements in the name of power and sovereignty" (kindle 190-91). In an effort to resolve or end the struggle, then, dialectics can serve to shut down the dissent that otherwise would (and must!) remain to act as a catalyst for change. In order to "decolonize dialectics" it is vital to always work to keep the dialectic open by "foregrounding rupture and shunning the lure of unity" (kindle 265). And this, I believe, is essentially what Allsup does in emphasizing openness. So, instead of synthesis and resolution, which tend to preserve Master/apprentice relationships, the dialectical struggle is revolutionary, yielding new relationships and new differences. Allsup writes: 
The beauty of pluralism speaks to the fact that there are more meanings available in music, as in life, than we can ever account for-more perspectives, more truths, more ways of knowing. Conceptually, this assertion is not strictly about "letting more in" or expanding the canon. Rather, I'm talking about something that is at once terribly unsafe and terribly light-a voyage beyond, a search outside oneself, a movement beyond one's field. (140-41)

Maybe some of our "actions for change" have erred on the side of amelioration, trying to find the middle ground-to reach consensus. Perhaps we should pay more heed to calls for dissensus (notably in ACT, Gould 2008 and Schmidt 2008). An open philosophy, one that foregrounds rupture and revolution as Allsup does, could be useful in avoiding a unity that may have the propensity to shut down struggle and to silence dissent (precipitating the end of history). Unity is different from solidarity. Unity means united as one (emphasizing sameness) while solidarity connotes working together for the same cause (emphasizing diversity). If we are not careful, solidarity can morph into unity and thereby impede revolutionary change. For example, drawing again from Ciccariello-Maher (2017):

For many, the strength of the slogan of the 99 percent was its inclusivity, the laudable aspiration to gather rather than disperse our forces. But by asymptotically approaching the inclusion of everyone, we run the risk of sliding into far more treacherous territory, moving from rupture, division, and opposition toward the aspirational recasting of a near-total unity. If anything, this is the most ideological gesture of all, one that seeks to reconcile rupture with its opposite, taking refuge in the comforting idea that we are all in this together rather than engaging in risky solidarity against. (kindle 231-5)

Minor changes that are occurring in music education certainly reflect the combined efforts of diverse groups. Relative to horrific levels of suffering currently inflicted upon people and the environment, there is still much work that can and should be done, even within the field of music education-simply because this is the field in which we labor, but also because if we are not offering solutions, we may very well be contributing to the problems. The urgency of our cause should allow us (critical theorists, postmodernists, feminists, anti-racist theorists, and so forth) to work together in light of significant differences-some, for instance, confronted with their own racism, patriarchy, or heterosexism and others with their classism, ageism, ableism, or urbanormativity (anti-rural bias). I'm not talking about simply "celebrating diversity" here, but the pragmatic decision and resolve to continue engaging critically with each other while, at the same time, 
striving for emancipatory change in music education, in solidarity, with humility and openness.

In this issue of ACT, eight authors reflect on Remixing the Classroom. Rather than give an overview of each article as is customary, I will refer the reader to the abstracts, easily accessible with just a "click," written by the authors, and thereby more reliable than anything I could offer. The eight review essays are followed by a thoughtful, poetic, and gracious, albeit brief response from Randall Allsup, wherein he has chosen to not engage point-by-point with specific criticisms offered by the reviewers. Some readers may find this disappointing, that things are left so open, but in light of the book under review, it does make sense. Let's acknowledge our differences, loud and clear-but with humility-and then move forward, working in solidarity for emancipatory change in music education.

\section{References}

Allsup, Randall Everett. 2016. Remixing the classroom: Toward an open philosophy of music education. Bloomington and Indianapolis: Indiana University Press.

Agger, Ben. 2013. Critical social theories: An introduction. Third edition. NewYork: Oxford University Press.

Bowman, Wayne D., and Ana Lucía Frega. 2012. Afterword: But is it philosophy? In The Oxford handbook of philosophy in music education, edited by Wayne D. Bowman and Ana Lucía Frega, 495-507. New York: Oxford University Press.

Butler, Judith. 2005. Giving an account of oneself. New York: Fordham University Press.

Ciccariello-Maher, George. 2017. Decolonizing dialectics. Kindle edition. Duke University Press.

Eagleton, Terry. 2016. Materialism. Kindle edition. Yale University Press.

Esteva, Gustavo, and Madhu Suri Prakash. 2014. Grassroots postmodernism: Remaking the soil of cultures. Second edition. London: Zed Books Ltd. 
Gould, Elizabeth. 2008. Devouring the other: Democracy in music education. Action, Criticism, and Theory for Music Education 7/1: 29-44. http://act.may daygroup.org/articles/Gould7_1.pdf

Lakoff, George, and Mark Johnson. 1999. Philosophy in the flesh: The embodied mind and its challenge to Western thought. New York: Basic Books.

MayDay Group. 2012. Action ideals. http://www.maydaygroup.org/aboutus/action-for-change-in-music-education/\#.WZMeV9Pyu3J

Mills, Charles W. 2017. Criticizing critical theory. In Critical theory in critical times: Transforming the global political and economic order. New Directions in Critical Theory. Kindle edition. Columbia University Press.

Nietzsche, Friedrich. 1910. Human, all too human: A book for free spirits. Translated by Helen Zimmern. Edinburgh and London: T. N. Foulis. http://digitalassets.lib.berkeley.edu/main/b20790001_v_1_Booo773557. pdf

Regelski, Thomas A. 2006. Reconnecting music education with society. Action, Criticism, and Theory for Music Education 5 (2): http://act.maydaygroup. org/articles/Regelski5_2.pdf

Regelski, Thomas A. 2009. Curriculum reform: Reclaiming 'music' as social praxis. Action, Criticism, and Theory for Music Education 8 (1): 66-84. http://act.maydaygroup.org/articles/Regelski8_1.pdf

Shiva, Vendana. 2014. Foreword: The enclosure and recovery of the commons. In Grassroots postmodernism: Remaking the soil of cultures, second edition, by Gustavo Esteva and Madhu Suri Prakash. London: Zed Books Ltd.

Schmidt, Patrick K. 2008. Democracy and dissensus: Constructing conflict in music education. Action, Criticism, and Theory for Music Education 7 (1): 10-28. http://act.maydaygroup.org/articles/Schmidt7_1.pdf 